\section{Conservative treatment of dentigerous cysts in children: Report of two cases}

\section{Çocuk hastalarda dentigeröz kistin konservatif tedavisi: İki olgu sunumu}

\section{Asist. Prof. Dr. Sercan Kücükkurt}

Istanbul Aydın University, Faculty of Dentistry, Department of Oral and Maxillofacial Surgery, Istanbul

\section{Dr. Can Tükel}

Cukurova University, Faculty of Dentistry,

Department of Oral and Maxillofacial Surgery, Adana

\section{Assoc. Prof. Dr. Emre Barıs}

Gazi University, Faculty of Dentistry, Department of Oral Pathology, Ankara

Received: 30 April 2017

Accepted: 12 June 2017

doi: 10.5505/yeditepe.2017.29494

\section{Corresponding author:}

Asist. Prof. Sercan Küçükkurt Istanbul Aydın University, Faculty of Dentistry Department of Oral and Maxillofacial Surgery Besyol Mh. Akasya Sk. No: 6 Sefakoy Kucukcekmece 34100 Istanbul, Turkey

Tel: 05326205590

E-mail:skucukkurt@gmail.com

\section{ABSTRACT}

Dentigerous cyst (DC) is the most common odontogenic developmental cyst. However DCs are rare in the first decade of life. They are always associated with an unerupted or developing tooth. The classic treatment option is the enucleation of cyst and extraction of the involved tooth. However, in children due to the great regenerative potential, marsupialization or decompression should be considered as the first treatment option in order to preserve the chance of the associated permanent teeth's eruption. This article reports the treatment of DCs in a six-year-old male and a nine-year-old female child using decompression technique and management of the unerupted teeth in the affected areas.

Keywords: Dentigerous cyst, conservative treatment, decompression, children

\section{ÖZET}

Dentigeröz kistler (DK), en yaygın odontojenik gelişimsel kistlerdir. Bununla birlikte, DK'lar hayatın ilk on yılında nispeten nadiren görülür. DK'lar daima yeni oluşmakta olan veya gömülü kalmış dişler ile ilişkilidir. Klasik tedavi seçeneği, kistin enükleasyonu ve ilgili dişin ekstraksiyonudur. Bununla birlikte çocuklarda, yüksek rejeneratif potansiyelleri nedeniyle, bölgedeki kalıcı dişlerin sürme şansını da artırmak için marsupializasyon veya dekompresyon ilk tedavi seçeneği olarak düşünülmelidir. Bu makale, altı yaşındaki bir erkek ve dokuz yaşındaki bir kız çocuğunda dekompresyon tekniği sayesinde DK'larin tedavisi ve bölgedeki dişlerin sürdürülmesini rapor edilmektedir.

Anahtar Kelimeler: Dentigeröz kist, konservatif tedavi, dekompresyon, çocuk hasta

\section{INTRODUCTION}

Dentigerous cysts (DC) are rare in the first decade of life and only $4-9 \%$ of them occur in this period. ${ }^{1}$ Clinically, it is asymptomatic and incidentally diagnosed during routine radiographic examination. ${ }^{2}$ Traditional treatment involves enucleation of the cyst and extraction of the surrounding teeth. However considering the rapid recovery in children, it can also be treated with marsupialization or decompression. ${ }^{3}$ This article reports the treatment of DCs in children using decompression technique and management of the unerupted teeth.

\section{CASE REPORT}

\section{Case 1}

A nine-year-old girl was referred to our department regarding to a swelling in the right side of the mandibula. In the clinical examination, a healthy mucosa covered expansion was detected in buccal sulcus of the right mandibular deciduous molar teeth (Figure 1). In radiography, a large unilocular radiolucent lesion was detected between the contralateral lateral incisor and the permanent first molar. The first premolar 
tooth was located in a 90-degree angle to the inferior distal of the cyst and the canine tooth was located in the mesial border (Figure 2).

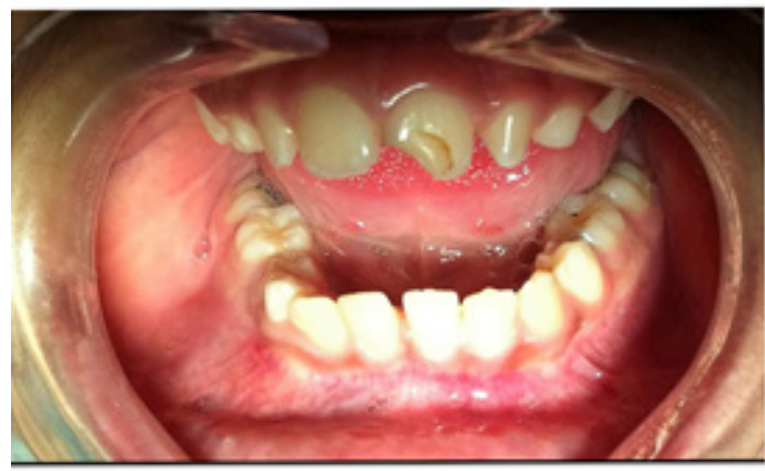

Figure 1: Pre-operative intraoral image

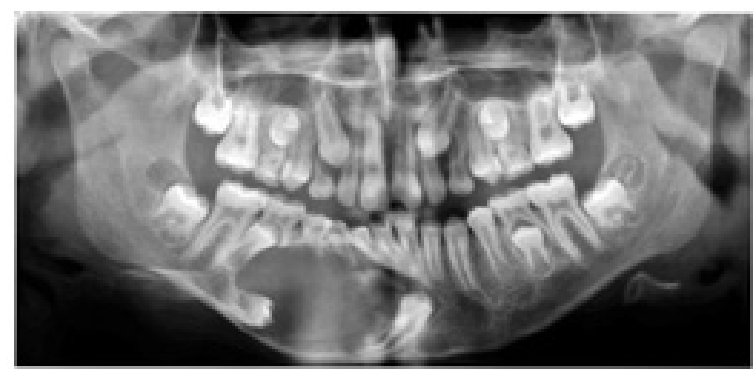

Figure 2. Orthopantomography images (Preoperative)

The lesion was initially diagnosed as DC and decompression was decided. After the removal of the deciduous molar teeth, a thick cystic epithelium was seen through extraction socket. Incisional biopsy was made and a pre-prepared insulin syringe was placed and sutured inside the cyst cavity (Figure 3 ).

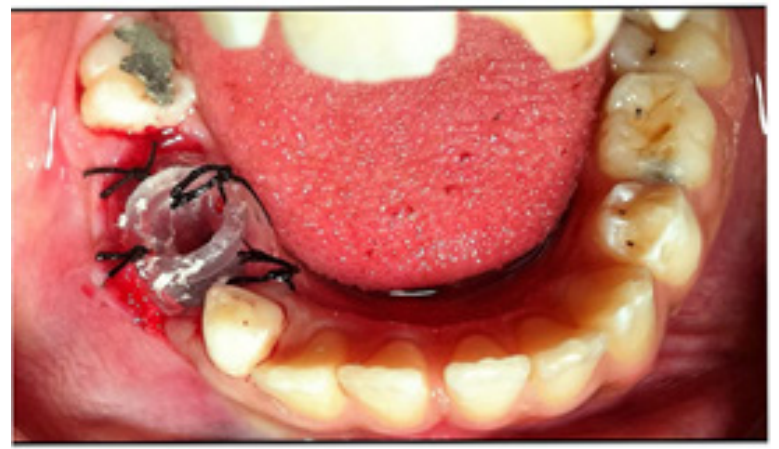

Figure 3: Placement of insulin syringe

The parents were informed that the cyst cavity should be rinsed twice daily through the insulin syringe using saline solution. The histological diagnosis was DC which was transforming into a keratocyst (Figure $4 \mathrm{~A}, \mathrm{~B}$ ).

Four months after the surgery, a significant shrinkage in the cyst and a clear alignment in the axis of the teeth were observed (Figure 5). After consultation with orthodontist and it was decided to clean the rest of the cystic epithelium and remove the second premolar due to its risk of blocking the eruption the canine (Figure 6). After two months from second surgery, despite the cystic lesion was completely disappeared, canine tooth did not fully erupt (Figure 7). Orthodontic treatment was planned to align the teeth and to help the canine tooth erupt. Within 10 months after, all the teeth were aligned; the canine tooth erupted (Figure 8). In the second year follow-up, no relapse was detected.

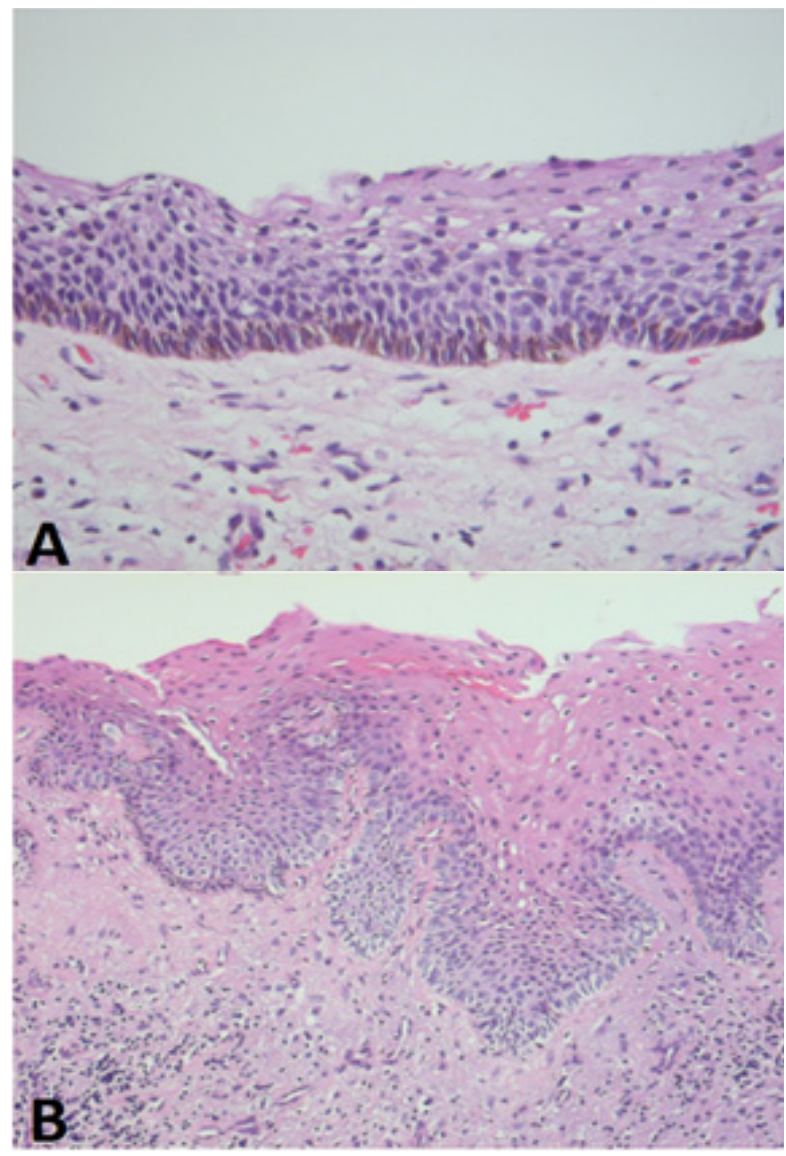

Figure 4A: Odontogenic keratocyst paved with epithelium which showing fencestyle sequence in the parakeratinized basal layer. B: Squamous metaplasia in the epithelial lesion (H\&E; A: x200, B: x100)

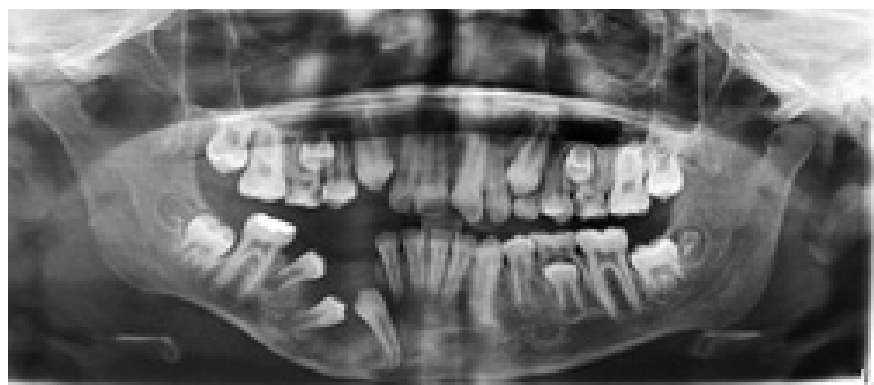

Figure 5. Orthopantomography images 4 month after surgery

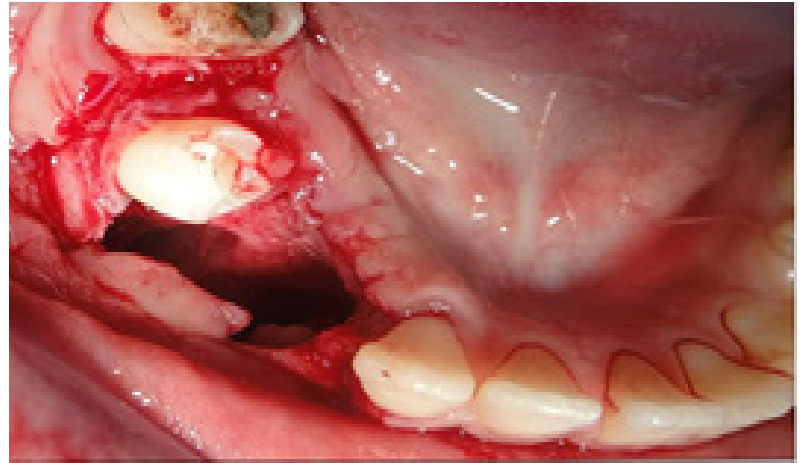

Figure 6: Enucleation of the rest of the cyst and extraction of first premolar 


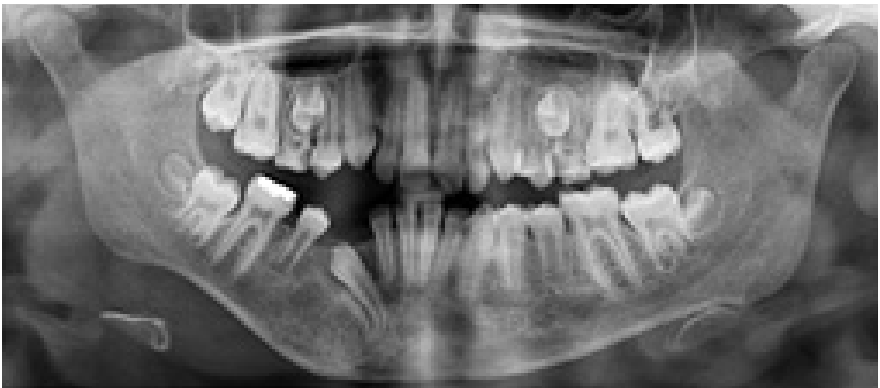

Figure 7: Sixth month follow -up

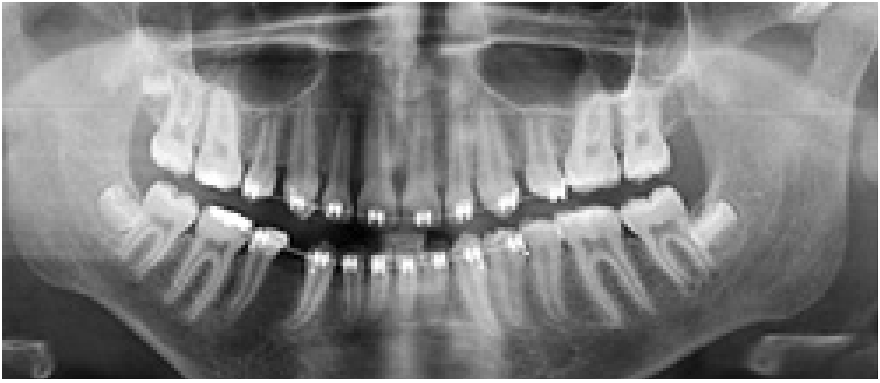

Figure 8: Second year follow-up

\section{Case 2}

A six-year-old boy consulted to our department due to a swelling in the right maxillary premolar area. In the clinic examination a large swelling reaching from the right deciduous lateral tooth to the right permanent first molar tooth detected (Figure 9).

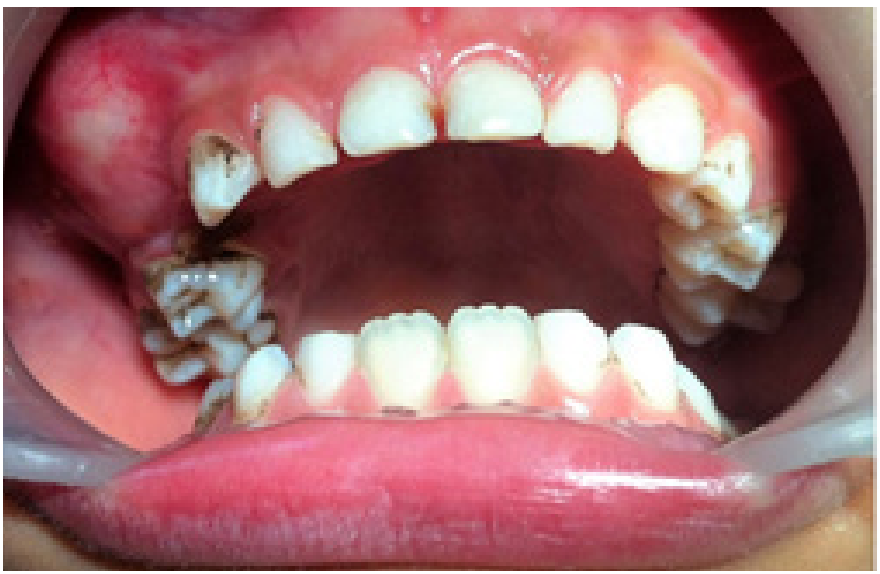

Figure 9: Pre-operative intraoral image

Radiologic examination revealed a radiolucency in this area, associated with canine and second premolar. In addition, first premolar was absent (Figure 10).

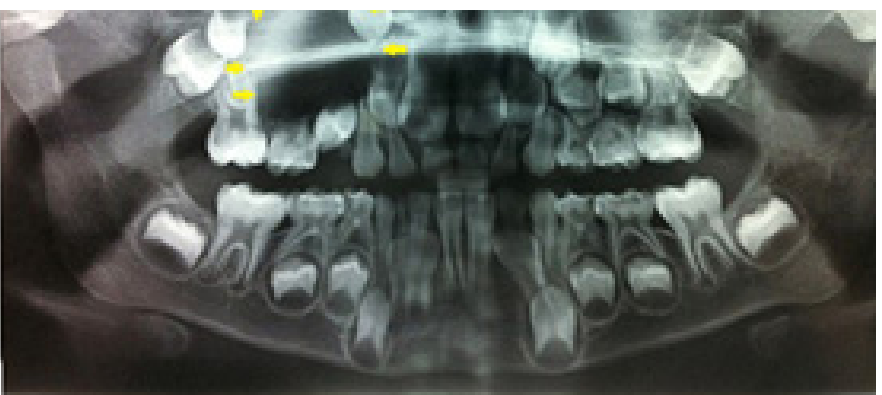

Figure 10: Preoperative image

Considering the age of the patient, the cyst decided to be treated with decompression. An insulin syringe was placed and sutured inside the cyst cavity (Figure 11).

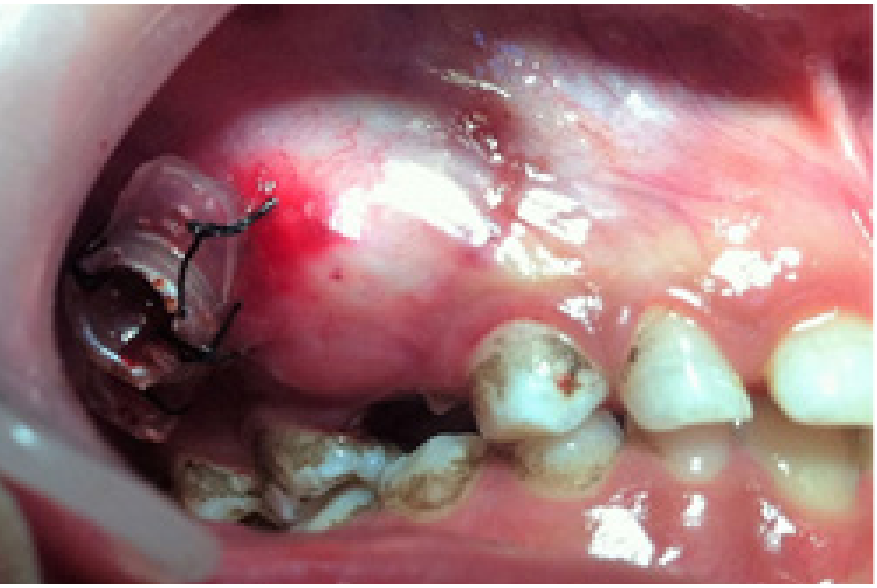

Figure 11: Placement of insulin syringe

During the procedure, an incisional biopsy was made and the diagnosis was DC. The area was rinsed twice daily for four months through insulin syringe by the parents. When the cyst reached an acceptable size, enucleation was carried out and unerupted second premolar tooth was extracted (Figure 12).

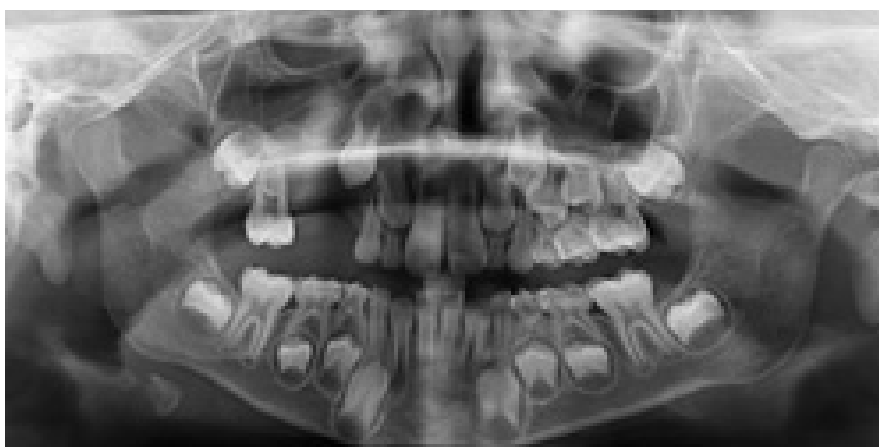

Figure 12: Sixth month follow-up

In the second year follow-up, it was seen that the area was completely recovered and the canine tooth was in the appropriate position (Figure 13).

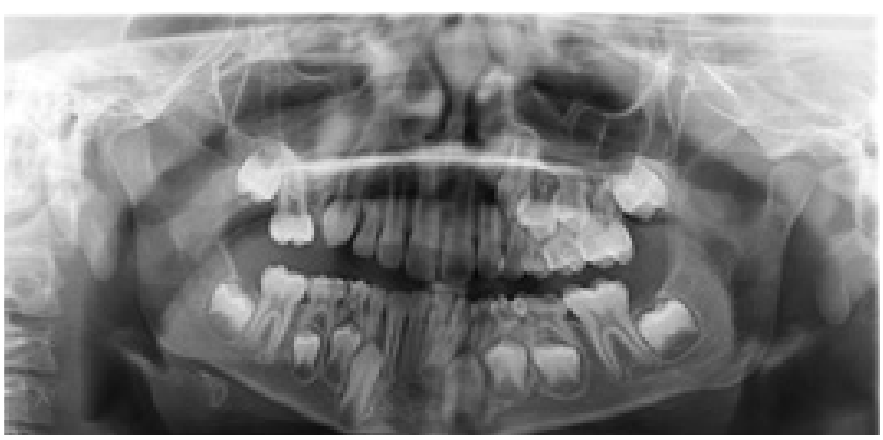

Figure 13: Second year follow-up

\section{DISCUSSION}

DCs occur as a result of fluid accumulation between the dentin and the tooth crown. The enlargement in the area is related to increased osmolality due to inflammatory cells and desquamated epithelium cells passing through the cyst lumen. ${ }^{4}$ Differential diagnosis includes eruption cyst, idiopathic bone cyst, lateral periodontal cyst, unicystic ameloblastoma, ameloblastic fibroma and odontogenic keratocyst. ${ }^{2}$

DCs can show an epithelium transformation and areas with orthokeratinization can contain ciliated cells or cells 
that secrete mucin. Therefore some long undetected DCs can turn into aggressive lesions such as odontogenic keratocysts, ameloblastoma, mucoepidermoid carcinoma or squamous cell carcinoma. ${ }^{5,6}$ In one of our cases, transformation to odontogenic keratocyst was detected in the pathological examination.

Orthopantomography is usually enough to determine the borders of the DCs. Under certain circumstances, computed tomography can be a useful technique to especially evaluate large lesions and determine their relations to other anatomic forms. In our cases, orthopantomography was enough for decompression technique which has low risk of damaging anatomical structures. ${ }^{3,4}$

The surgical treatment of DCs usually involves enucleation and the removal of the unerupted teeth. An alternative treatment is marsupialization, which involves creating an opening in the deepest point of the cystic cavity. However it is hard to trust this treatment option because of the difficulty of maintaining the opening without a drainage material. Thanks to decompression treatment, the cyst can be freed from important anatomic forms and these forms do not suffer during a possible enucleation. Also a late secondary enucleation after decompression can be done if it is necessary. ${ }^{7}$

Since in one of our case the cyst was related to inferior alveolar nerve and in the other one was related with maxillary sinus, firstly the shrinkage of the cyst and late secondary enucleation was planned. In addition, it was thought that the time required for the decompression would allow the guided eruption of the teeth and development of the roots. However, the disadvantages of the technique are that mostly the patient performs the cleaning of the cavity and the patient is required to conform the periodic follow-ups.

Compared to adult patients, pediatric patients recover quickly and also unerupted teeth are more likely erupt. However, eruption depends on various factors such as the age of the patient, the location of the cyst, and the location of the tooth in relation to the cyst, axial slope and the degree of root formation. ${ }^{8}$ Fujii et al. ${ }^{9}$ reported that during the marsupialization, the rate of eruption of the teeth surrounding the cyst is $72 \%$. In our cases, one apiece unerupted premolars were extracted.

According to Tolstunov ${ }^{10}$ ideal decompression material should not move into the cavity; it should be easily fastened to the surrounding tissues and remove when necessary; and allow the cavity to be effortlessly cleaned daily without sacrificing hygiene. The insulin syringe used in our case had nearly all the features suggested by the author except for the rigidity of the material.

This case presentations show a simplified surgical procedure which can be implemented under clinical conditions using local anesthesia for pediatric patients with a large DC. Also this procedure creates the best chance for save the unerupted teeth. On the other hand this technique requires frequent monitoring by the doctor and regular maintenance of the area by parents of the patient.

\section{REFERENCES}

1. Deboni MC, Brozoski MA, Traina AA, Acay RR, Naclerio-Homem Mda G. Surgical management of dentigerous cyst and keratocystic odontogenic tumor in children: a conservative approach and 7-year follow-up. J Appl Oral Sci 2012; 20: 282-285.

2. Demiriz L, Misir AF, Gorur DI. Dentigerous cyst in a young child. Eur J Dent 2015; 9: 599-602.

3. Park HS, Song IS, Seo BM, Lee JH, Kim MJ. The effectiveness of decompression for patients with dentigerous cysts, keratocystic odontogenic tumors, and unicystic ameloblastoma. J Korean Assoc Oral Maxillofac Surg 2014; 40: 260-265.

4. Ziccardi VB, Eggleston TI, Schneider RE. Using fenestration technique to treat a large dentigerous cyst. J Am Dent Assoc 1997; 128: 201-215.

5. Gay-Escoda C, Camps-Font O, Lopez-Ramirez M, VidalBel A. Primary intraosseous squamous cell carcinoma arising in dentigerous cyst: Report of 2 cases and review of the literature. J Clin Exp Dent 2015; 7: e665-670.

6. Kimura $\mathrm{T}$, Ohba $\mathrm{S}$, Yoshimura $\mathrm{H}$, Fujita $\mathrm{S}$, Imamura $\mathrm{Y}$, Kitagawa $Y$, Sano K. Keratocystic odontogenic tumor arising at the mandibular ramus with an impacted tooth: a case report and mimic lesions. Cranio 2015; 29: 1-8.

7. Tucker WM, Pleasants JE, MacComb WS. Decompression and secondary enucleation of a mandibular cyst: report of case. J Oral Surg 1972; 30: 669-673.

8. Scariot $R$, da Costa $D J$, Rebellato NL, Muller PR, Gugisch RC. Treatment of a large dentigerous cyst in a child. J Dent Child (Chic). 2011; 78: 111-114.

9. Fujii R, Kawakami M, Hyomoto M, Ishida J, Kirita T. Panoramic findings for predicting eruption of mandibular premolars associated with dentigerous cyst after marsupialization. J Oral Maxillofac Surg 2008; 66: 272-276.

10. Tolstunov L. Marsupialization catheter. J Oral Maxillofac Surg 2008; 66: 1077-1079. 
